Mavi Atlas, 9(1)2021: 28-41

Makale Geliş | Received: 02.01.2021

Makale Kabul | Accepted: 12.03.2021

DOI: 10.18795 /gumusmaviatlas. 852406

Araştırma Makalesi | Research Article

\begin{abstract}
Ayhan DEVER
Doç. Dr. | Assoc. Prof. Dr.

Ordu Üniversitesi, Beden Eğitimi ve Spor Yüksekokulu, Ordu-TÜRKIYYE

Ordu University, School of Physical Education and Sports, Ordu-TURKEY

ORCID: 0000-0002-8300-5290

ayhandever@odu.edu.tr
\end{abstract}

Sinem Toprak ATEŞOĞLU

Sosyolog | Sociologist

ORCID: 0000-0002-2561-1540

sinem@atesoglu.web.tr

\title{
McDonaldlaştırma ve Simülasyon Teorileri Bağlamında Postmodernizm ve Spor
}

\section{$\ddot{O} z$}

Moderniteye bir başkaldırı olarak ortaya çıkan postmodernizmin, toplumsal hayatın hemen her alanına etkide bulunduğu, değiştirdiği ve dönüştürdüğü ifade edilmektedir. Bu değişim ve dönüşümden sanat, edebiyat, mimari, müzik vb. alanlar daha fazla oranda etkilenmektedir. Buna bağlı olarak dünya postmodern anlayış doğrultusunda yeniden şekillendirilmekte ve buna uygun yeni tarzlar ortaya çıkmaktadır. Bunun yanı sıra postmodernizmin, toplumsal bir kurum olarak spora olan etkilerinden de söz etmemiz mümkündür. Bu etkiler doğrultusunda postmodern döneme ait yeni bir spor anlayışı ortaya çıkmıştır. Bu çalışmanın amacı postmodernizmin spora bakışını ortaya koymaktır. Çalışmada postmodern teoriler olarak ifade edilen McDonaldlaştırma ve Simülasyon teorileri, sporla ilişkilendirilmeye çalışılmıştır. Bu amaç doğrultusunda öncelikli olarak McDonaldlaştırma teorisinin dört temel boyutu (hesaplanabilirlik, öngörülebilirlik, verimlilik, denetim) spora uyarlanmış ve spor olgusunun bu dört temel boyuta uygun bir şekilde açıklanabileceği ortaya çıkmıştır. Bir diğer postmodern teori olarak Simülasyon teorisi ele alınmış, teorinin temel kavramlarından birisi olan hiper - gerçeklik düşüncesi spora uyarlanmaya çalış1lmıştır. Özellikle televizyon futbolu bağlamında ele alınan hiper - gerçeklik düşüncesinin, televizyon futbolunun, simüle edilen gerçeklikten daha da gerçeklik taşıdığı sonucuna ulaşılmıştır. Ayrıca bahsi geçen postmodern teorilere dayanarak oyun kurallarının, oyunu daha da hızlandıracak şekilde değiştirildiği ve taraftarlık anlayışının da bir değişim içerisine girerek, doğrudan tüketime odaklanan ve maçları evlerinde televizyon karşısında izleyen post-taraftarların ortaya çıktığı sonucuna ulaşılmıştır.

Anahtar Kelimeler: Spor; Postmodernizm; McDonaldlaştırma Teorisi; Simülasyon Teorisi.

\section{Postmodernism and Sports in the Context of Mcdonaldization and Simulation Theories}

\begin{abstract}
It is stated that postmodernism, which emerged as a rebellion against modernity, affected, changed and transformed almost every area of social life. Art, literature, architecture, music, etc. are the areas that are most affected from this change and transformation. Accordingly, the world is reshaped in line with the postmodern understanding; therefore, new styles have been emerging. In addition, it is possible to talk about the effects of postmodernism on sports as a social institution. In line with these effects, a new understanding of sports has been emerged in the postmodern period.The purpose of this study is to reveal views of postmodernism on sports. Mcdonaldsization and Simulation theories, which are expressed as postmodern theories, have been tried to be associated with sports. In line with this purpose, four basic dimensions of McDonaldsization theory (calculability, predictability, efficiency, control) have been adapted to sports, and it has been revealed that the phenomenon of sports can be explained in accordance with these four basic dimensions. Simulation theory has been discussed as another postmodern theory, and hyper - reality phenomena, one of the basic concepts of the theory, has been tried to be adapted to sports. It was concluded that the idea of hyper - reality, which is considered in the context of television football, carries more reality than the simulated reality of television football. In addition, based on the aforementioned postmodern theories, it was concluded that the rules of the game were changed in a way to accelerate the game and that the understanding of fans has started to change, resulting in post-fans focusing on direct consumption and watching the matches in front of television at home.
\end{abstract}

Keywords: Sport; Postmodernism; McDonaldization Theory; Simulation Theory. 


\section{DEVER, Ayhan ve Sinem Toprak ATEŞOĞLU (2021). "McDonaldlaştırma ve Simülasyon Teorileri Bağlamında Postmodernizm ve Spor”, Mavi Atlas, 9(1): 28-41}

\section{Giriş}

Postmodernizm terimi, günümüzde popülerliğini geçmiş dönemlere nazaran bir parça yitirmiş olsa da gündelik hayatımızın hemen her alanına sirayet eden bir anlatı hâline gelmiştir. Mimaride, edebiyatta, sanatta yaygın bir şekilde kullanılan 'postmodern tarz' veya 'postmodern yaklaşım' gibi ifadeler, kulakların kelimeye daha fazla aşina olmasını sağlamıştır. Terim, bir bilim olarak sosyolojide de yeni anlayışların, yeni bakış açılarının ortaya çıkmasını sağlamış; toplumsal yapıya ait postmodern anlatılar hızlı bir şekilde gelişim göstermiştir.

Ne’liği konusunda bir fikir birliğine varılamamış olsa da postmodernizme yönelik çalışmalarda öncelikli açıklamalar modernizm kavramına verilmiştir Zira postmodernizm, modern ötesi veya modernliğe bir başkaldırı olarak düşünülmüş ve modernizmi anlamadan, postmodernizmin açılkanamayacağ ifade edilmiştir.

İçerisinde bulunduğumuz postmodern çağ, pek çok alana etki etmekte ve toplumsala ilişkin çeşitli unsurları değişime uğratmaktadır. Değişime yönelik bu etkiler özellikle sanatta, edebiyatta, mimaride ve çeşitli sosyolojik kurumlarda belirgin bir şekilde hissedilmektedir. Postmodernizmin etki ettiği alanlardan bir tanesi de spor olmuştur. Sporda belirgin bir şekilde değişimlerin meydana gelmesi, postmodern döneme has bir özellik olarak ifade edilebilir.

Bu bağlamda postmodernizmin spora olan etkilerini açıklayabilmek amacıyla çalışmada, postmodern teorilerden ikisi olarak ifade edilen George Ritzer'in McDonaldlaştırma ve Jean Baudrillard'in Simülasyon teorilerine yer verilmiş ve bu teorilerin söylemleri, genel anlamda sporla açıklanmaya çalışılarak spor ve postmodernizm arasındaki ilişki ortaya konmaya çalışılmıştır.

\section{Postmodernizm Nedir?}

Özellikle 2000'li yıllara kadar daha yoğun bir şekilde kullanılan postmodernizm terimi, beraberinde birtakım belirsizlikleri de getirdiği için tanımlanması biraz zordur. Bu nedenle de postmodernizm kavramını açıklayabilmek amacıyla, öncelikli olarak modern, modernizm ve modernlik gibi kavramlara kısaca değinilmesi daha uygun olacaktır. Zira kavram içerisinde yer alan '-post' ekinin, genel anlamda karşı gelme, isyan etme şeklinde bir içeriğe sahip olduğu düşünülmekte ve postmodernizm, bu ek ile birlikte, modernliğe, moderniteye bir başkaldırı, karşı gelme durumunu bünyesinde barındırıyor gibi görünmektedir.

\subsection{Modern, Modernizm ve Modernlik Kavramları}

Modern terimi, gündelik hayat içerisinde yapılan vurgularla, 'şu anı' veya 'günümüzü' akıllara getirmektedir. Diğer bir ifade ile geçmiş dönemler, modern olmayan dönemlerdir şeklinde bir ifade de ortaya konabilir. Bir kavram olarak 'modern', Latincede modernus kelimesinden türetilmiş, modernus ise köken olarak modo ifadesinden ortaya çıkmıştır. Modo, Latince de 'hemen şimdi' anlamına gelmektedir (Kızılçelik ve Erjem, 1996: 385). Modern kelimesinin varlığının, Hristiyan dönemi ile Pagan dönemi arasında bir ayırt edici unsur olarak 5. yüzyıla kadar uzandığına inanılmaktadır. Kavramın kökeninin, genellikle 1690'ların başında Paris'teki Fransız Akademisi ( L'Acade'mie Française)'nden, modern kültürün, klasik Yunan - Roma kültüründen üstün olup olmadığı konusunda edebi ve sanatsal tartışmalardan kaynaklandığı düşünülmektedir (Madsen, 2014: 1199-1200).

Özgün ve en genel anlamıyla modern kelimesi, çağdaş, güncel veya bugün anlamına gelmektedir. Kelime, günümüzün ve yakın zamanların müziğini, kıyafetlerini, mimarisini, tutumlarını ve sosyal kalıplarını daha uzak geçmişinkilerle karşılaştırmaktadır. Sosyoloji bilimi de, modern sosyal teoriye atıfta bulunurken, onu daha eski 'klasik' teorilerle karşılaştırarak kullanır. Kavram ayrıca, modern Britanya'yı, İngiliz tarihi içerisinde, daha önceki dönemlerle karşılaştırmak için de kullanılmaktadır. Modernlik üzerine düşünen ilk yazarlar, 17. yüzyıl Avrupasının yükselen 


\section{DEVER, Ayhan ve Sinem Toprak ATEŞOĞLU (2021). "McDonaldlaştırma ve Simülasyon Teorileri Bağlamında Postmodernizm ve Spor", Mavi Atlas, 9(1): 28-41}

ticari ve ulusal toplumlarını, feodalizmin zayıflayan yapıları ve diğer tüm geleneksel toplum biçimleriyle karşılaştırdılar (Scott, 2006: 110-111).

Modernlik kavramı ise daha ziyade modern toplumları tanımlayan ve onları, kendisinden önceki oluşumlardan ayıran birtakım özellikler paketini ifade etmektedir. Modernitenin ne zaman ortaya çıktığına dair bazı anlaşmazlıklar olsa da, aşağıda yer alan özellikler listesiyle ilgili olarak yaygın bir görüş birliği bulunmaktadır; endüstriyel kapitalist ekonomiler, demokratik siyasi örgütlenme, sınıfa dayalı esnek bir sosyal yapı (Bruce ve Yearley, 2006: 201).

Modernlik, genellikle gelenekselliğe zıt olarak görülmüş ve geleneksellikten kopuşu temsil ettiği düşünülmüştür. Eğer geleneksellik geçmişe bakmaksa, modernlik muhtemelen gözünü geleceğe çevirmektir. Modern ifadesi sıklıkla; ilerleme, gelişme, özgürleşme, büyüme, birikim, aydınlanma gibi kelimelerle ilişkilendirilmektedir (Kivisto, 2011: 132-133).

Modernlik teriminin, daha ziyade Rönesans'la birlikte ortaya çıtı̆̆ kabul edilmiş ve Antik Yunan ve Roma uygarlıklarıyla bağlantılı olarak tanımlanmaya çalışılmıştır. Dönemin etkili alanlarından birisi olan Alman sosyoloji kuramının bakış açısıyla modernlik, ilerici düzeyde iktisadi ve yönetsel ussallaştırmaya ve sosyal dünyanın ayrımlaştırılmasına vurgu yapmaktadır. Diğer bir ifadeyle modernlik, Batı uygarlıklarında 18. yüzyıl civarında ortaya çıkan, sosyal, ekonomik ve siyasal dizgilere vurgu yapan şemsiye bir terimdir (Sarup, 2004: 186).

Bugün bildiğimiz şekliyle sosyal teori, entelektüeller 19. yüzyılda olgunlaşan moderniteyi anlamlandırmaya başladıkları zaman gelişmeye başlamıştır. Bununla birlikte, erken dönem modern teorisyenler, modernitenin nasıl tanımlanması gerektiği konusunda fikir birliğine varamamış ve bu anlaşmazlıkların çoğu sonraki nesillerde de devam etmiştir. Modernitenin temel parametreleri, çeşitli erken dönem kuramcıların, modernite tarihinin ilk taşı1ııları olduğunu savundukları dinamik güçler dikkate alınarak kavranabilir. Örneğin Adam Smith ve Karl Marx'a göre piyasalar veya kar odaklı üretim biçimindeki kapitalizm, modern toplumsal yaşantının temelini oluşturmuştur. Saint Simon ve Auguste Comte, bilimsel bilgi ve teknolojinin nihayetinde moderniteyi rasyonel ve düzenli bir şekilde yönlendireceğini savunmuştur. E'mile Durkheim, modern bireycilik kültürünü ve işbölümünü vurgulamıştır. Bununla birlikte, çağdaş teorisyenlerin çoğu, askerî güçleri, bürokrasi, yarg1 sistemi, eğitim sistemleri ve gelir kaynakları da dâhil olmak üzere ulus-devleti, modernitenin bir başka dinamik gücü olarak görmüşlerdir (Turner, 2006: 389-90).

Sosyolojik çalışmaların çoğu, modern öncesi ve modern toplumlar arasında keskin bir ayrım olduğu varsayımına dayanmaktadır. Modernite, ekonomik, politik, sosyal ve kültürel temellerde ayırt edilmektedir. Örneğin, modern toplumlar tipik olarak endüstriyel, kapitalist ekonomilere, demokratik siyasi örgütlenmeye ve sosyal sinıflara bölünmeye dayalı bir sosyal yapiya sahiptir. Hayatın tüm yönlerinin metalaşmasını, rasyonelleştirilmesini ve günlük yaşamın hızlanmasını içerdiği söylenen kültürel özellikler konusunda daha az fikir birliği bulunmaktadır. Modernite, yeni bireysel gözetim, disiplin ve kontrol sistemlerine ihtiyaç duymuştur (Abercrombie et all, 2006: 253).

Modernlik, birkaç özellikle daha net bir hâle getirilebilir. Teknolojinin gelişmesi ve üretimin sanayileşmesi, fizik ve sosyal bilimlerindeki teorik devrimler, büyük ölçekli demografik hareketler, tüketici kapitalizminin büyümesi, çok uluslu şirketlerin sayısının artması, araçsal aklın ve bürokrasinin normalleşmesi, ulus devletlerin büyümesi ve genel bir dünya ekonomisinden söz edilebilir olması (Taylor, 2005: 115) gibi özellikler, modern döneme has belli başlı birtakım özellikler olarak ifade edilebilir. Bu özelliklerden hareket ederek modernliğin bir tanımı yapılacak olursa; modernlik, "bilimsel bilgi, endüstriyalizm, teknoloji, teknikleştirme, uzmanlaşma, demokrasi, laiklik düşüncesi ve bireyselleşme eksenleri etrafinda toplumsal yaşam alanlarını düzenlemeye yönelik bir proje” (Kızılçelik, 1996: 14) olarak belirtilebilir. 


\section{DEVER, Ayhan ve Sinem Toprak ATEŞOĞLU (2021). "McDonaldlaştırma ve Simülasyon Teorileri Bağlamında Postmodernizm ve Spor”, Mavi Atlas, 9(1): 28-41}

\subsection{Postmodernizm'in Ne'liği}

Mike Featherstone'nun da belirttiği gibi (1996: 18) postmodernizm teriminden söz etmek, oldukça sığ ve anlamsız bir hevese süreklilik kazandırmakla suçlanma riski taşımaktadır. Bu konudaki en önemli sorunlardan birisi terimin kullanılmasının oldukça moda olmasına karşın, tanımlanmasinın zor olmasidır.

Postmodernizm, farklı araştırmacılar tarafindan, farklı şekilde tanımlanan bir terimdir. Diğer bir ifade ile terim, kolay bir şekilde özetlenmeye, formüle edilmeye karşıdır. Bununla beraber postmodernizmden söz eden araştırmacılar, sosyal gruplar arasındaki mücadele içerisinde yaratılan karmaşı güç, bilgi ve söylem ilişkilerini keşfetmeye kararlıdırlar. Ayrıca postmodernizm, işin her zamanki gibi yürütülmesine meydan okuyan birkaç perspektifle iç içe geçmiştir. Bahsi geçen perspektifler arasında feminizm, neo-Marksizm, postyapısalcllı ve postkolonyalizm bulunmaktadır (Taylor, 2005: 113).

Postmodernizm terimi, ilk olarak 1930'lu yllarda Federico de Onis tarafindan modernizme karşı bir tepkiyi anlatmak amacıyla kullanılmıştır. 1960'lı yıllarda ise birtakım sanatçı, eleştirmen ve yazar grubu tarafından yüksek modernizmin ötesine geçen bir hareketi ifade etmek için kullanılmış, 1970 - 80’li yıllardan itibaren ise mimari ve sanatın çeşitli alanlarında daha geniş bir kullanıma ulaşmıştır (Featherstone, 1996: 28). Madan Sarup ise (2004: 188) kavramın ilk defa 1960'lı yllarda New York'ta bulunan sanatçılar ve eleştirmenler arasında kullanıldığını ve 1970'li yıllarda Avrupalı kuramcılar tarafindan şekillendirildiğini ifade etmektedir. Kavram uzun bir geçmişe sahip olmamakla birlikte öncelikli olarak sanat alanında kullanılan bir ifade iken, sonrasında sosyal bilimlerde de egemen olmaya başlamıştır.

Postmodernizm teriminin neliğine dair yaygin inanış, -post önekinden kaynaklanan bir sonralığı ve moderniteye karşı bir başkaldırıyı içerdiği şeklindedir. Buna karşın, postmodernite, anti modernite veya non modernite değildir, 'post' modernitedir. Aynı şekilde postmodernizm, anti veya non modernizm değildir, 'post' modernizmdir (Arslan, 2000: 2).

Postmodernizm kısmen Aydınlanma geleneğinden doğan pozitivist felsefenin radikal bir yapısökümünü ifade etmektedir. Postmodernizm, bilimin kendisinin ayrıcalıklı bir akıl veya hakikat aracı olduğu şeklindeki modernist dogmanın özüne itiraz ederek yalnızca bilimsel bilginin güvenli bir şekilde temellendirilebileceği şeklindeki pozitivist iddiayı reddetmektedir. Sosyal teorinin temel rolü olarak sosyal araştırma için kavramsal zemini güvence altına almak olduğu fikrini reddeder. Son olarak postmodernizm, bilimin tarafsız olduğu veya olması gerektiği yönündeki modernist görüşü eleştirerek, bilimin pratik ve ahlaki anlamını vurgulamaya çalışır. Postmodernizm, sosyal, politik ve üslup hareketleri ile ekonomi ve toplumdaki değişimler hakkındaki görüşleri kucaklayan bir tür ekümenik şemsiye olarak da görülebilir. Sanat, feminizm, ekoloji, teoloji, politika ve hatta bilimlerdeki hareketleri içerir. Ekonomik değişimle ilgili fikirler açısından postmodernizm, postendüstriyel toplum teorilerine yayılır. Bu tür fikirler (diğer şeylerin yanı sıra) iletişimdeki artışa, bilginin artmasına, tüketim toplumunun sonuçlarına, boş zamanın yükselişine ve Baudrillard'ın simülasyon dediği şeye atıfta bulunmaktadır (Quie, 2000: 276-277).

Postmodernizm "modernliğin temel parametrelerine, eş deyişle, bilimsel bilginin üstünlüğüne, pozitif bilimlere, doğrusal gelişmeye, ulus - devlet anlayışına, endüstriyalizme, kapitalizme, demokrasiye, laikliğe, insan haklarına, teknolojiye, bürokrasi ve uzmanlaşmaya karşı gelen ve onları sorgulayan, buna karşın belirsizliğe, parçalılığa, farklılığa, etnikliğe, alt - kültürlere, kültürel çoğulculuğa, bilgiye yönelik çoğulcu bakış açısına, yerel bilgiye, yerelliğe, özgünlük ve Özgüllüklere ayrıcalık tanıyan bir hareket” (Kızılçelik, 1996:28) olarak açıklanabilir.

"Postmodern teori, modernleşmeyi, yabancılaşma, monotonlaşma, tatminsizlik ve hazc1lı̆̆a yol açtı̆̆ı, orijinallik ve farklılıkları yok ettiğinden dolayı eleştirir, özellikle de modernitenin ruhunun ruhsuzluğuna işaret eder. Postmodern teorisyenler, modernliğin tüm yönlerine karşı 
DEVER, Ayhan ve Sinem Toprak ATEŞOĞLU (2021). "McDonaldlaştırma ve Simülasyon Teorileri Bağlamında Postmodernizm ve Spor”, Mavi Atlas, 9(1): 28-41

çıkar"'Kızılçelik, 2002:166). Postmodern teori, modernitenin açmazlarına, modernitenin eleştirisine dayanır. Bu nedenle de modernlik içerisinde bulunan bütün özelliklere bir karşı gelme, onlara meydan okula durumu söz konusudur.

1980'lerde ve 1990'larda postmodern sosyal teoriler, sosyal bilimler alanında çeşitli açıklamalar yapmaya başlamıştır. Genel olarak Nietzche, Derrida, Baudrillard, Lyotard ve diğer isimler, postmodernizm ile ilişkilendirilmiştir. Postmodern düşünürler, sosyal bilimlerde bir postmodern dönüşümün ortaya çıttğını, giderek artan bir şekilde post - endüstriyel, tüketimci, küreselleşen bir dünyayı anlamlandırmak için bu kavramın kullanıldığını ifade etmişlerdir (Giulianotti, 2015: 171).

\section{Postmodern Teoriler ve Spor}

Çalışmanın bu kısmında çeşitli postmodern teoriler, sporla ilişkilendirilmeye çalışılmıştır. $\mathrm{Bu}$ amaç doğrultusunda George Ritzer'in McDonaldlaştırma ve Jean Baudrillard'in Simülasyon teorilerine yer verilmiş; bahsi geçen postmodern teorilerin anlatıları doğrultusunda teorilerin diğer bir ifade ile postmodernizmin, spora bakışı ortaya konmaya çalışılmıştır.

\subsection{McDonaldlaştırma Teorisi ve Sporun McDonaldlaştırılması}

McDonaldlaştırma teorisi, bir fast-food zinciri olan McDonald'sların sayısının artması ve insanların buralarda sürekli olarak bir şeyler tüketmeleri şeklinde bir çağrışım yapıyor olsa da Ritzer tezinde, McDonald's gibi ikonik bir küresel şirketi, gündelik hayatın yeniden düzenlenmesinde daha geniş bir süreci örneklemek için kullanmıştır (Waring and Bishop, 2015: 491).

Ritzer'in McDonaldlaştırma teorisi, Weber'in rasyonellik teorisinin yeniden şekillendirilmesi olarak ifade edilebilir. Weber, rasyonaliteyi, Batı toplumlarının bilimsel ve ilerici zihniyetlerine göre ayırt etmeye çalışmıştır. Bu rasyonalite biçimi, yalnızca amaçlara ulaşmanın optimum yollarını tanımlamakla kalmamış, aynı zamanda süreçleri kurallar ve düzenlemeler aracıllğıyla da kurumsallaştırarak zaman ve mekâna aktarılabilir hâle getirmiştir. Rasyonalite, Weber'in 'demir kafes’ olarak tanımladığı bürokratik olarak organize edilmiş olan sosyal bir düzen üretir. Ritzer, Weber'in teorisini genişletmiş, McDonaldlaştırma sürecinin, üretimin resmileştirilmesinin çok ötesinde, daha çağdaş bir rasyonalizasyon biçimini temsil ettiğini ileri sürmüş̧ür (Ahuvia and Bilgin, 2011: 361). McDonaldlaştırma, rasyonalizasyonun yeniden kavramsallaştırllması veya geleneksellikten rasyonel düşünce tarzına ve bilime geçilmesini ifade etmektedir.

Ritzer ortaya koymuş olduğu teorisinin, Weber'in rasyonalleşme düşüncesine dayandığını ancak farklı bir model benimsediğini ifade etmektedir. O'na göre Weber, bürokrasiye odaklanmışken, kendisi fast-food restoranlarına yoğunlaşmıştır. Bunun yanı sıra, McDonaldlaştırma teorisi, Weber'in rasyonelleşme kuramını, 21. yüzyıla getirmiş ve rasyonelleşmenin Weber'in hayal ettiğinden daha fazla bir şekilde dünyanın daha fazla bölgesine ulaştığını ifade etmektedir (Ritzer, 2012: 451).

Ritzer, çalışmasına McDonald's restoranlarının isim haklarının dünya genelinde satılmasıyla ortaya çıkan tüketim çılgınlığına vurgu yaparak başlamaktadır. Bu yayılım ile birlikte McDonald’s restoranlarının kazancı daha da artmıştır. Örneğin 1993 yılında toplam satışlar 23,6 milyar dolara ulaşmıştır. 1993 yılının sonuna kadar dünya genelinde yaklaşık 14.000 McDonald's restoranı vardır (2011: 22-23). Bu rakam 2019 yllı verilerine göre 38.695'tir ve McDonald's restoranlar1, her gün yaklaşık olarak 69 milyon müşteriye hizmet vermektedir (McDonald's Report, 2020). Diğer bir ifade ile günlük müşteri sayısı, neredeyse İngiltere'nin toplam nüfusuna eşit düzeydedir.

Dünyanın içerisinde bulunduğu tüketim çılgınlığından hareket eden Ritzer, McDonaldlaştırma'nın dört farklı boyutundan bahsetmektedir. Diğer bir ifade ile McDonaldlaştırma'nın başarılı olmasında dört temel unsur etkili olmuştur. Bunlar; verimlilik, hesaplanabilirlik, öngörülebilirlik ve denetimdir (Ritzer, daha sonradan bu unsurlar arasına 


\section{DEVER, Ayhan ve Sinem Toprak ATEŞOĞLU (2021). "McDonaldlaştırma ve Simülasyon Teorileri Bağlamında Postmodernizm ve Spor”, Mavi Atlas, 9(1): 28-41}

rasyonelliğe bir eleştiri olarak 'rasyonelliğin irrasyonelliği' kavramını da eklemiştir. Ancak bu çalışmada rasyonelliği ön plana çıkartan ilkelere odaklanıldığı için ilk dört unsur değerlendirmeye alınmıştır).

Verimlilik boyutu, bir noktadan diğerine gitmek için en uygun olan yolu sunmaktadır. $\mathrm{Bu}$ durum tüketiciler için, McDonald's restoranlarının, açlıktan doymaya geçmek için en iyi yolu sunması anlamına gelmektedir (Ritzer, 2011: 34). McDonaldlaştırılmış üretim araçları, en yüksek verimlilik arayışlarıyla dikkat çekmektedir. Ekonomik açıdan işletmeler, malzeme ve insan kaynaklarının minimum kullanımı ile maksimum kar elde etmeye çalışmaktadır. Fastfood restoranları için bu durum, mümkün olduğunca az kaynakları kullanarak, daha çok hamburger, patates kızartması ve içecek satmak anlamına gelmektedir. Ritzer, fast-food restoranlarının üretim sürecini düzene sokarak, standart bir hâle getirerek ve otomatikleștirerek aynı zamanda tüketim sürecini de hızlandırarak işlerin verimliliğini artırma çabalarını açılamaya çalışmıştır (Sandvoss, 2003: 106).

Verimlilik boyutu, Ritzer'e göre spora en kolay uyarlanabilen boyutlardan bir tanesidir. O'na göre özellikle yeni yapılan stadyumlar, kolay bir şekilde otoyollara ulaşma imkânı sağlamakta ve büyük otoparklara sahip bir şekilde tasarlanmaktadır. Yürüyen merdivenler, kolay bir şekilde, taraftarların hareket etmesini sağlamaktadır. Özellikle de yağmur ve kardan dolayı maçın oynanmamasını önlemek amacıyla stadyumlara kubbeler yapılmıstır. Yapay çim bulunan stadyumlar ise yağmur suyunu daha kolay bir şekilde ve daha fazla oranda tahliye ettiğinden dolayı daha fazla oranda tercih edilir bir hâle gelmiştir. Aynı durum spor salonları için de geçerlidir. Spor salonlarından daha fazla verim elde edebilmek amacıyla içerisinde pek çok alet bulunmakta ve salonlara gelen bireyler, bedenlerinin nerelerini etkin bir şekilde çalıştırmak istiyorlarsa, ona göre bu aletlerden istifade etmektedirler (Ritzer, 2011: 98-99).

Bunun dışında McDonaldlaştırma'nın verimlilik boyutu özellikle futbol müsabakalarına ve taraftarlara da uyarlanabilmektedir. Sportif etkinlikler için verimlilik boyutu, maç biletlerinin satılması olarak ifade edilebilir. Sportif etkinlikler için bilet satın almak geçmişe göre oldukça değişmiştir. Eskiden bilet almak için, havalar veya şartlar ne olursa olsun bilet satış gişelerine gitmek gerekirken günümüzde ise bilet bayilerinin yerini teknoloji almıştır. Doğrudan bir şekilde taraftarlar, internet aracılığıyla biletlerini kolay bir şekilde satın alabilmektedirler. Böylece taraftarlar / müşteriler, bir yandan maçları izlemek amacıyla kendileri için bilet satın alarak kendilerine hizmet etmekte, diğer yandan da kulübün biletlerinin satılmasını sağlayarak kulüp için çalışmaktadırlar (Churchill, 2005: 2). Taraftarlar, biletleri internet üzerinden satın alarak hem kendi işlerini halletmiş olmakta hem de kulüplerine, insan gücüne dayanmayan bir şekilde, destek sağlamaktadırlar. Çünkü sıraya girerek gişelerden bilet almak boşa geçen süreyi uzatırken zaman kaybına neden olmakta ve buna bağlı olarak verimlilik daha da düşmektedir.

Bunun yanı sıra futbol kulüpleri de, kendi varlıklarından maksimum düzeyde faydalanabilmek amacıyla karlarını arttırma çabası içerisindedirler. Futbol takvimindeki boşlukları doldurmak, futbol temelli piyangoları ve çeşitli oyunları yaz aylarında ayakta tutmak amaciyla tasarlanan çeşitli yerel lig oyunları (UEFA Toronto Kupası vb.), genişletilmiş oyunlar veya Şampiyonlar Ligi gibi müsabakalar, genel anlamda futbol kulüplerinin kendi üretim araçlarından (stadyum, antrenör, futbolcu) maksimum düzeyde yararlanma çabasıdır (Sandvoss, 2003: 106-107). Diğer bir ifade ile futbol kulüplerinin yıl içerisinde oynadıklanı oyunların sayısı postmodern dönemde daha da arttırılmış, buna karşın oyunun kalitesi biraz daha geri plana atılmıstır. Önemli olan daha fazla kar elde edebilmek amacıyla artan müsabakalar için taraftarların, bilet satın almaları olmuştur. Bu şekildeki bir uygulama kulüpler için, doğrudan doğruya verimi arttırmaya diğer bir ifade ile fazla bir çaba sarf etmeden, kulüpler için bir gelir sağlama durumu olarak belirtilebilir. 


\section{DEVER, Ayhan ve Sinem Toprak ATEŞOĞLU (2021). "McDonaldlaştırma ve Simülasyon Teorileri Bağlamında Postmodernizm ve Spor”, Mavi Atlas, 9(1): 28-41}

Taraftarların, verimi arttırmaya yönelik rolleri, çabaları burada bitmemektedir. Ritzer'e göre fast-food restoranları içerisinde müşterilerin çeşitli rolleri bulunmaktadır; burgerlere çeşitli soslar eklemek, yiyecekleri self-servis olarak almak gibi (2011: 104). Bu durum doğrudan bir şekilde verimin artmasına yönelik bir özellik olarak belirtilebilir. Özel birtakım soslar aracıllğıyla, ürünlerin tadı kötü olsa bile, bu olumsuz durum soslar aracıllğıyla kamufle edilmekte, self-servis olması ise müşterilerin daha kısa süre içerisinde yemeklerini yemelerini ve buna bağlı olarak yeni müşterilerin gelmesini sembolize etmektedir.

Aynı durum spor taraftarları içinde geçerlidir. Taraftarlar, maç günü stadyumlara geldikleri zaman, takım oyuncularının daha verimli bir şekilde oynamaları için şarkılar söylemekte ve tezahüratlar yaparak futbolcuları alkışlamaktadırlar. Böylece taraftarlar, profesyonel futbolun ortaya çıkmasına ve tüketilmesine katkıda bulunmaktadırlar. Futbol tüketiminin ezici bir çoğunluğunun televizyon aracılı̆̆ıyla gerçekleştiği postmodern dönemde, futbol kulüplerinin nispeten az sayıdaki müşterileri, bir spor ürününün vazgeçilmez bir parçası olan atmosferik yapısını ortaya koymak için canla başla çalışmaktadırlar (Sandvoss, 2003: 107). Futbolcuların daha iyi oynamalarını sağlamak amaciyla yapılan tüm aktiviteler ve profesyonel futbolun atmosferik yapısının sağlanması, doğrudan bir şekilde taraftar grupları aracıllğıyla oluşturulmakta ve buna bağlı olarak, spor kulüpleri bu durumdan başarıya bağlı olarak dolaylı yoldan daha fazla oranda kar elde etmektedirler.

Elbette ki bu durumdan günümüzün modern stadyumları olarak adlandırılan Disneystad'lar da payını almaktadır. Günümüzde futbol tüketiminin mabedi konumunda olan modern stadyumlarda, locaların sayısının arttı̆̆ını görmekteyiz. Bu durumun tersi de geçerlidir; daha fazla loca olması için koltuk kapasiteleri azaltılmıştır. Bu durumun bir sonucu olarak spor kulüpleri, verimliliklerini arttırmak, daha fazla kar elde edebilmek amacıyla locaların fiyatlarını daha da arttırmışlardır. Hatta bunu gerçekleştirebilmek amacıyla bilet fiyatlarının arttırılmasından da söz etmemiz mümkündür. Bu nedenle stadyumu bir üretim alanı olarak gören futbol kulüplerinin daha fazla verimlilik anlayışı, katı tüketim rejimleriyle sonuçlanmıştır. Taraftarlar, ancak futbol kulüpleri tarafından bu tür etkinliklerin rasyonelleştirilmiş üretiminin taleplerine göre günlük yaşamlarını düzenlemeye hazırlarsa oyunlara katılabilir hâle gelmişlerdir (Sandvoss, 2003: 109-110).

McDonaldlaştırma'nın bir diğer boyutu ise hesaplanabilirliktir. Hesaplanabilirlik, ürünlerin nicel özellikleri ve sunulan hizmet diğer bir ifade ile zaman olarak belirtilebilir (Ritzer, 2011: 35). Hesaplanabilirlik boyutu, doğrudan bir şekilde sayılabilen, ölçülebilen şeylere vurgu yapmaktadır: alınan ürünün boyutları, ne kadara mal olduğu ve ürünü alırken geçecek olan süre vb. Diğer bir ifade ile ürünün tadı, şekli ve görüntüsü bu aşamada pek dikkate alınmamaktadır.

Spor karşılaşmalarının, oyunun doğrudan bir şekilde sonuca, farklı rakamlarla yenme yenilme - berabere kalma mantığı içerisinde hazırlandığını ve bittiğini görürüz. Sporcuların nasıl oynadıklarından ziyade, her zaman skor tabelasının geçerliliği vardır ve sonucu tabeladaki rakamlar belirlemektedir. Elbette ki bu rakamların çok olması takımın başarısını ortaya koyar ve puan cetvelinde de üst sıralarda yer almasını sağlayabilir. Ancak takımın başarısını doğrudan bir şekilde rakamlarla ölçmek, sporun hesaplanabilir olmasına vurgu yapmaktadır.

Stadyum dışında futbol maçlarının ve turnuvalarının pazarlanma şekli de hesaplanabilirliğe vurgu yapmaktadır. Dünya Kupası, Avrupa Şampiyonaları, Şampiyonlar Ligi ve hatta çeşitli yerel müsabakalar, 'yllın en büyük maç', 'gelmiş geçmiş en büyük turnuva', 'yllın derbisi' gibi isimlerle anılmaktadır. Geçmiş dönemlerde pek çok örneği olduğu gibi en büyük maçlar genellikle en eğlenceli olmaktan uzaktır. Sporun yönetim organları, sakatlanan oyuncuların derhal sahadan

\footnotetext{
1 Disneystadlar, taraftarın futbol ibadetini yerine getirdikleri, kışın 1sıtılan, yazın serinletilen, içerisinde eğlence merkezleri, sinemalar, alış-veriş merkezleri, localar, store’lar, hediyelik eşya dükkânları, lokantalar, lüks restorantlar bulunan; taraftarların asla çıkmak istemedikleri, rahat bir şekilde maçı izledikleri futbolun yeni merkezleridir. Konuyla ilgili daha fazla bilgi için bkz: Dever, A. (2013).
} 


\section{DEVER, Ayhan ve Sinem Toprak ATEŞOĞLU (2021). "McDonaldlaştırma ve Simülasyon Teorileri Bağlamında Postmodernizm ve Spor”, Mavi Atlas, 9(1): 28-41}

çıarılması ve başka bir yerde tedavi edilmesi emrini vererek, yaralanmalardan kaynaklanan zaman kaybını en aza indirgemeye yönelik bir çaba içerisine girmişlerdir. Bir futbol karşılaşmasında taraftarlara en az 90 dakikalık bir oyun garanti edilmektedir (Sandvoss, 2003: 114).

Bunun dışında spor ürünlerine bakacak olursak, örneğin Adidas'ın Adidas Predator isimli futbol ayakkabısı, hesaplanabilirlik boyutuna örnek olarak verilebilir. Bu ayakkabı fazla miktarda üretilmekte, esas olarak bu ayakkabıları giyen yıldız sporculara odaklanılmakta, reklamlarda izleyici kitlesi, Beckham'ın topa özgürce vurduğu ve sonuca ulaşmada (gol atmada) bu ayakkabının yardımcı olacağına inandırılmaya çalışılmaktadır. Adidas, ayakkabının kalitesine vurgu yapmazken Umbro ise daha az sayıda üretim yapmakta ve ayakkabının kalitesine vurgu yapmaktadır (Churchill, 2005: 2-3). Bu noktada Adidas firmasının yaptığı, McDonaldlaştırma'nın hesaplanabilirlik boyutuna örnektir. Çünkü bu ayakkabı aracıllğ̆1yla kolay bir şekilde gol atılacağı ve skor tabelasındaki rakamların yükseltilebileceği belirtilmektedir. Bunun yanı sıra hesaplanabilirlik boyutunda, ayakkabının kalitesine, kullanılan malzemelerin içeriğine yer verilmediği görülmektedir.

McDonaldlaştırma'nın bir diğer boyutu olan öngörülebilirlik ise ürün ve hizmetlerin her zaman her yerde aynı olacağını ifade etmektedir (Ritzer, 2011: 36). Diğer bir ifade ile öngörülebilirlik, bir fast-food zincirinin bütün ürünlerinin, nerede olursa olsun aynı özelliklere sahip olacağ1 gerçekliğidir. Her ne kadar spor özellikle de futbol, öngörülemez bir alan olsa da ve hatta onu asıl çekici kılan bu öngörülemezlik olsa da, Ritzer, özellikle yeni yapılan spor sahalarından hareket ederek, spordaki öngörülebilirliği açıklamaya çalışmıştır. Ritzer, beysboldaki profesyonel takımların kubbe stadyumları ve yapay yüzeyler aracılığıla sporun kendisinin, öngörülebilirliğini nasıl ilerlettiğini belirtmektedir. Geçmiş dönemlerdeki açı stadyumlar, doğa şartlarına karşı hiçbir koruma sağlamamışken, günümüzde taraftarların büyük ölçüde değişen maçlara katılım oranlarıyla, oyunun atmosferik kalitesi de önemli ölçüde değişim göstermiştir. Leverkusen ve Chelsea kulüplerinin sahalarının değişimi öngörülebilirlik alanındaki ilk çalışmalardır. Her iki saha da koltuklu sahalardır. Çatı kaplaması, taraftarları yağmurdan ve aşırı güneş ışığından korumaktadır. Leverkusen'in stadyumuna kış aylarında tribünleri ısıtan bir sistem de kurulmuştur. Her iki sahanın da nispeten küçük kapasitesi, taraftarların stadyumu doldurmasını ve buna bağlı olarak her maçta uygun atmosferi garanti etmektedir. Entegre sirt desteğine sahip modern plastik koltuklar, neredeyse evdeki oturma düzenlerine benzeyen maksimum bir konforu garantilemektedir (Sandvoss, 2003: 117-118). Modern stadyumlar, genel anlamda bir öngörülebilirlik sunmakla beraber, aynı zamanda daha önce de belirtildiği gibi verimlilik boyutuna da katkı sağlamaktadır.

Bir spor taraftarı, bir maç veya basın toplantısı gördügünde, maçı kaybetmek veya basın toplantısında düzensiz davranışlar görmek istememektedir. Maçı kazanmak, kendilerini güvence altına almak ve rutini bozmamak için öngörülebilir konuşmalar duymak istemektedirler (Churchill, 2005: 3). Diğer bir ifade ile bütün taraftarlar, takımlarına yönelik herhangi bir öngörülmezliğe karş1 temkinlidir. Her şeyin belirli bir şekilde gözlerinin önünde cereyan etmesini istemektedirler.

McDonaldlaştırma'nın son boyutu ise denetimdir. Denetim, insan teknolojisinin yerini, insansiz teknolojinin alması sayesinde yapilan kontroldür (Ritzer, 2011: 37). Profesyonel futbolda, McDonaldlaştırma ile benzer özellik, müşterileri kontrol etme çabasının derecesidir. Ritzer, fast food dükkânlarında müşterilerin geçirdikleri zamanı en aza indirgeme çabalarına atıfta bulunmaktadır. Fastfood dükkânlarının sade, birbirine benzer, floresan aydınlatmalı içyapıları buna bir örnektir. Futbol kulüpleri, daha da katı kontrol önlemleriyle bilinmektedir. Nisan 1989'daki Hillsborough felaketinde 97 Liverpool taraftarının öldüğü olaya kadar, seyirciler çitlerle çevrili alanlarda oturmuştur. Bugün futbol sahalarındaki kontrol mekanizmaları daha da belirgin bir hâle gelmiştir. Her seyirci için bir koltuk bulunmakta, kameralar sürekli olarak kayıt yapmaktadır (Sandvoss, 2003: 116). Spor sahalarının, maç günlerinde sürekli olarak bir denetim altında tutulması, taraftarların CCTV kameralarla sürekli olarak kayıtlarının alınması denetimin en bilinen boyutudur. 


\section{DEVER, Ayhan ve Sinem Toprak ATEŞOĞLU (2021). "McDonaldlaştırma ve Simülasyon Teorileri Bağlamında Postmodernizm ve Spor”, Mavi Atlas, 9(1): 28-41}

Böylece herhangi bir olumsuz duruma anında müdahale edilmekte ve futbolda denetim boyutu var olmaya devam etmektedir.

\subsection{Simülasyon Teorisi, Televizyon Futbolu ve Post-Taraftarlık}

Fransız sosyolog Jean Baudrillard, postmodern döneme damga vurmuş ve özellikle simülakr, simülasyon ve hiper-gerçeklik kavramlarıyla ön plana çıkmış bir isimdir. O'nun Simülasyon teorisinin temel kavramlanından birisi olan simülakr, 'bir gerçeklik olarak algılanmak istenen görünüm'(Baudrillard, 2011: 7) şeklinde ifade edilmektedir. Simüle etmek, gerçek olmayan bir şeyi gerçekmiş gibi sunmak, göstermeye çalışmak olarak tanımlanırken, simülasyon ise 'bir araç, bir makine, bir sistem, bir olguya özgü işleyiş biçiminin incelenme, gösterilme ya da açıklanma amacıyla bir maket ya da bir bilgisayar programı aracıllğıyla yapay bir şekilde yeniden üretilmesi' (Baudrillard, 2011:7) şeklinde tanımlanmaktadır. Baudrillard simülasyon kavramını, içerisinde bulunduğumuz post-modern dünyanın, gerçek bir toplum değil, -mış gibi yapılan bir şey, sembol ve kopyaların, gerçek ve somutun yerini aldığı sanal bir realite olduğunu göstermek amaciyla kullanmıştır (Slattery, 2012: 470). Hiper - gerçeklik, hem simüle edildiği hem de "gerçekten daha gerçek" olduğu anlamında, aşırı ayrıntıya dikkat ile karakterize edilen bir simulakrum olarak dünyadır (Giulianotti, 2004: 233). Diğer bir ifade ile hiper - gerçeklik, genel anlamda gerçeklik ile yapay olan arasındaki sinırların ortadan kalkmasıdır.

Baudrillard tarafindan ortaya konan Simülasyon teorisine göre çağımızda imaj, taklit ya da simülasyon, gerçekliğin yerini almıştır (Cevizci, 1999: 775). Simülakr sistemi ile ilgili olarak Disneyland'1 kusursuz bir örnek olarak gören Baudrillard'a göre Disneyland eğlence merkezleri içerisinde, bütün simülakr düzenler iç içe geçmiş durumdadır. O’na göre; Disneyland, bir illüzyon ve fantezi oyunudur. Disneyland'ın yoğun bir şekilde ilgi görmesinin nedeni çelişkileri ve güzellikleriyle birlikte gerçek Amerika'nın minyatürleştirilmiş bir kopyasını sunuyor olmasındandır. Buradaki olağanüstü tek şey, ziyaretçilerine pek çok duyguyu bir arada yaşatan çok sayıda oyun ve oyuncağın var olmasıdır. Disneyland'ın her köşesinde bir Amerikan modeliyle karşılaşmak mümkündür. $\mathrm{Bu}$ alan içerisinde Amerika'nın sahip olduğu bütün değerler, minyatür hâline getirilmiş, çizgi filmler aracıllğıyla çoğaltılmış ve ziyaretçilerin kendilerinden geçmesi sağlanmaya çalışılmıştır. Disneyland, gerçeğe değil, hiper-gerçeğe ve simülasyona aittir (Baudrillard, 2011: 2930). Disneyland'e Ana Cadde'den girilmekte ve içerisinde klasik Amerikan şehirlerinde bulunan bir alıs - veriş merkezi de bulunmaktadır. Pek çok turist, gerçek bir akvaryuma veya okyanusa gitmek yerine Disneyland'deki denizaltı simülasyonu gezilerine katılmaktadır. Disneyland'de hiçbir şey gerçek olmamakla birlikte önceden yazılmış senaryolara göre hareket etme durumu söz konusudur. İçerisinde yaşadığımız dünyada gerçek ve doğru olan bir şey kalmamış ve bundan dolayı dev bir simülasyon içerisinde yaşar hâle gelinmiştir (Ritzer, 2012: 208).

Baudrillard, dünyay1, hiper - gerçeklik olarak ifade etmektedir. Özellikle de medya, gerçekliğin bir aynası olmaktan çıkarak gerçeklikten daha gerçek bir hale gelmiştir. Televizyonda sunulan sahtelikler ve çarpıtmalar, gerçeklikten daha fazla bir özelliğe sahiptir, hiper - gerçekliktir. Diğer bir ifade ile gerçek olan ikincil hâle gelmiş veya tamamen yok olmuştur. Gerçeklik daha fazla düzeyde hiper - gerçek hâle gelmiştir (Ritzer, 2012: 495). 'Biri Bizi Gözetliyor' veya 'Issız Ada' gibi dizi ve çeşitli televizyon programları, ilişkilerin simüle edildiği sözde gerçeklik örnekleri sunmaktadır. Diğer bir ifade ile bizler, hayatın televizyon içerisinde ve televizyonun da hayatın içerisinde kaybolduğu bir dönemde yaşamaktayız (Slattery, 2012: 471).

Medya, hiper - gerçekliğin; gerçeklik ve simülasyon ise kafa karışıklı̆ıının ayrılmaz bir parçasıdır. Baudrillard, yalnızca sosyal olanın hayatta kaldığı fikrini reddetmekte, bunun yerine sadece televizyon teknolojisinin, toplumsalın ölü bedenini 1sıtabileceğini savunmaktadır. Hiper gerçekliğin en kötü şöhretli örneği ise Baudrillard'ın 'Körfez Savaşı gerçekleşmedi’ iddiasında yer 


\section{DEVER, Ayhan ve Sinem Toprak ATEŞOĞLU (2021). "McDonaldlaştırma ve Simülasyon Teorileri Bağlamında Postmodernizm ve Spor”, Mavi Atlas, 9(1): 28-41}

almaktadır. O'na göre bu savaş hiper - gerçek bir olay, bir televizyon anı, sanal, dolayımlı bir çatışmaydı ve savaştaki ölümler önemsizdi (Giulianotti, 2004: 234).

Baudrillard'ın düşünceleri spora uyarlanabilir durumdadır. Özellikle de hiper - gerçeklik ve simülasyon kavramları, televizyon futbolunu açılamada önemli bir yere sahiptir. Milenyum çağında televizyon futbolu, daha kapsamlı ve ayrıntılı bir hâle gelmiştir. Sürekli olarak değişen çekimler, farklı açılar, pozlar, pozisyon tekrarları, zamanın (görüntünün) yavaşlatılması veya hızlandırılması vb. pek çok unsur, simülasyona doğru bir geçiş oluşturduğundan dolayı, oyunun gerçeklik referansı daha sorunlu bir hâle gelmiştir. Oyunun kendisi, kendi simülasyonuyla tanınmış ve referans noktası olmaktan ziyade onun bir gölgesi olmuştur. Günümüzde taraftarlar için referans noktası, televizyon futbolunun simülasyonu olmuştur. Pek çok taraftar için televizyon futbolu, hiper- gerçeklik hâline gelmiştir (Scambler, 2005: 131).

Baudrillard, insanların artan bir şekilde evlerinde televizyonda olayları deneyimlemeyi tercih ettikçe, deneyimin doğrudan alakasız hâle geleceğini, futbol maçlarının boş stadyumlarda, izleyicilerin yapay görüntüleri ve seyirci gürültüsüyle oynanabileceğini iddia etmiştir (Malcolm, 2008: 135). Bu düşüncesini desteklerken, Eylül 1987'de İspanya'nın Madrid kentinde Real Madrid ile Napoli arasında oynanan Avrupa Kupası maçına atıfta bulunmuştur. Madrid taraftarlarının bir önceki maçtaki asi davranışları nedeniyle, futbol yetkilileri, maçı seyircisiz bir stadyumda oynanmasına karar vermiş ve karşılaşma televizyon aracıllŏgyla taraftar kitlelerine aktarılmıştır. Böylece, "hayalet bir futbol maç" gerçekleşmiş ve bu durum, postmodern sporun geleceğini şekillendirmiştir; hiçbir taraftarın olayları doğrudan deneyimlemeyeceği, ancak isteyen herkesin karşılaşmanın bir imajını izleyeceği' bir spor şekli ortaya çıkmıştır (Andrews, 2000: 129).

Taraftarların stadyumlara alınmaması durumu, "bağlamından kopartılan gerçek bir olayın, boşlukta gerçekleştiği ve yalnızca uzaktan, televizyon görüntüsü olarak görülür olduğu dünyamızın terörist hiper - gerçekçilini çok iyi gösteriyor... Olayın küçük ayrıntılarını kimse yaşamış olmayacak, ama herkes görüntüsünü elde etmiş olacak" (Baudrillard, 1995: 77).

Postmodern dönemde çoğu profesyonel futbol maçı, futbol sahalarında değil, televizyon aracılı̆̆ıyla tüketilmektedir. Sahada maç izleyen taraftarlar, televizyon ekranlarında maçı izleyenlerden tamamen farklıdırlar. Televizyon futbolu ev merkezlidir ve günlük yaşamın ritmine tam olarak uymaktadır. İki veya üç saattir; bu nedenle seri ve hızlıdır, görsel olarak renkli ve hoştur. Diğer bir ifadeyle televizyon futbolu, bütün günlük pratikleri içerisinde barındıran (Sandvoss, 2003: 137) bir gerçeklik sunmaktadır.

Televizyon aracilı̆̆ılla sunulan hiper - gerçekliği kesintisiz ve daha hızlı bir şekilde verebilmek amacıyla oyun kurallarında da değişikliğe gidilebilmektedir. Kötümser bir bakıș açısıyla Harriss, kriket sporundaki bir dizi değişikliği, postmodernizmin bir müdahalesi olarak ifade etmektedir. Harriss, temel olarak kriketin hızlanmasına yönelik kural ve format değişikliklerini ifade etmektedir. Kriket sporundaki değişikliklerin çoğu, 1977'de World Series Cricket'in oluşumunu takiben daha popüler bir hâle gelen bir kriket çeşidi olan bir günlük kriket maçlarının tanıtımı esnasında ve sonrasında meydana gelmiştir. Sonuç olarak Harriss, kriketi, derinliği olmayan, gösterişli bir dış görünüşe sahip, merkezi olmayan bir gösteri olarak tanımlamaktadır. Harriss, eleştirilerinde kriketin indirgenmiş olduğu gösterişli aşırılık ve şatafatın beraberinde oyunun gerçekliğini kaybettiği düşüncesini getirdiğini belirtmektedir (Hughson et al. 2005: 100).

Spor sosyolojisinin önemli isimlerinden Richard Giulianotti, hızlı bir oyunun, iyi bir oyun olduğu şeklindeki Amerikan anlayışına uygun olarak, futbolda topun sahaya sokulması, kaleciye geri pas verme ve oyunun diğer kurallarının, oyunu hızlandırmak için değiştirildiğini (1999: 143) ifade etmektedir. Oyunun hızlandırılması, genel anlamda Amerikan yaşam tarzına atıfta bulunmakla birlikte, dünyanın en büyük simülasyon merkezi olan Amerikan yaşam tarzına ve oyun anlayışına atıfta bulunmaktadır. Taraftarların stadyumlara gitmeyerek maçları sanal bir kutu içerisinde gerçek 


\section{DEVER, Ayhan ve Sinem Toprak ATEŞOĞLU (2021). "McDonaldlaştırma ve Simülasyon Teorileri Bağlamında Postmodernizm ve Spor”, Mavi Atlas, 9(1): 28-41}

üstü bir olay olarak izlemelerine bağlı olarak, taraftarlar üzerindeki hiper - gerçeklik etkisini daha da arttırabilmek amacıyla oyun hızlandırılmış ve arada oyundan çeşitli kesintiler eklenmesiyle oyunun monotonlaşması önlenmeye çalışılmıştır. Amerika simülasyonunda yavaşlı̆̆a yer yoktur ve hiper - gerçeklik hızlı bir şekilde yaşamın devam ettirilmesini istemektedir.

Televizyon sporu, sayısız derecede gereksiz bilgi akışı sağlamaktadır; çoklu kamera açıları, oyunculara ait sayısal veriler vb. Teknoloji, kitlelere tercih ettikleri kamera açıları üzerinde yönetmenlik kontrolü vaat etmektedir. Uzakdoğu'da bulunan stadyumlara kolay bir şekilde sanal turlar yapılabilmektedir. Spor pratiği yaparken bile çim saha karşılaşmalarını, simüle edilmiş golf, kriket, beysbol veya futbol video oyunları ile değiş̧tirebilmekte diğer bir ifade ile gerçek olanı hiper - gerçekle değiştirmekteyiz. Spor stadyumlarına gelen taraftarlar için de deneyim giderek daha da hiper - gerçek olmaya başlamışır. Büyük spor organizasyonlarında kameralar, kitleleri sosyal bir olayı simüle etmek için şarkı söylemeye, tezahürat yapmaya ve alkışlamaya davet etmektedir. Sporun atmosferini veya geçmişteki spor kalabalıklarının sosyal kültürlerini simüle etmek için yeni bir hiper - gerçek seyirci kültürü biçimi ortaya çıkmaya başlamıştır. Bu seyirci gruplarının, söylediği tezahüratlar, büyük oranda medya reklamlarından alınmış; spor karşılaşmalarını etkilemek için değil de evde maç izleyen taraftarlara mesajlar vermek için pankartlar ve flamalar yaptırmışlardır. Taraftarların stadyum içerisinde pasif olduğu yerlerde, televizyon yöneticileri, saha içerisindeki atmosferi taklit etmek amaciyla yapay kalabalık gürültüsü seslerini, simüle edilmiş atmosfere aktarmaktadırlar (Giulianotti, 2004: 234-235).

Hiper - gerçeklik anlayışı içerisinde bazı taraftar gruplarının takıma olan bağlılıkları ve bağlantıları daha akıcı bir hâle gelmiștir. Post - taraftar taraftarlar olarak ifade edilen flâneur taraftarlar, diğger taraftarlarda olduğu gibi ateşli bir dayanışma biçimine sahip değildir. Bunun yerine spora olan ilgilerini ve takımlarına bağlılıklarını özgür bir şekilde değiştirme anlayışına sahiptirler. New York Yankee Beysbol takımının şapkasını, Chicago Bulls takımının tişörtünü, Brezilya milli futbol takımının formasını, göğsünde 'İtalia' yazan eşofman üstü gibi spor takımlarının ürünlerini satın alma eğilimindedirler. Flâneur kimlikleri, en azından spor takımı kimliğinin olası çöküşüne işaret eden, akışkan bir ulus-ötesi tüketiciliği daha somut bir hâle getirmiştir (Giulianottti, 2015: 240). Post - taraftarlar, geçmiş dönemlerde karşımıza çıkan takımının maçlarına sürekli giden, soğukta ve sıcakta takımları için tezahüratlar yapan, bilet satın alabilmek amacıyla gişelerde sıraya giren, takımlarının formalarını ve amblemlerini adeta kutsallaştıran 'klasik taraftar' olgusunun ötesinde, daha rahat ve stadyumdaki gerçekliği, televizyondan daha fazla bir gerçeklik olarak almaya çalışan taraftar tipleridir.

Post-taraftarlar, futbol, müzik ve modayla bağlantılı ilgi alanlarına sahip, kendine güvenen, refleksif, sanata ilgi duyan, stil sahibi popüler kültür bilgesidir. Post - taraftarlar, destekleme deneyimlerini tamamen ciddiye alan diğer taraftarların aksine, karşılaşmanın sadece bir oyun olduğunu bilerek, diğer taraftarlara ironik bir şekilde yaklaşmaktadırlar (Redhead,1997: 29-30). Post - taraftarlar, çağdaş futbolun doğasına uyum sağlamışlardır ve futbol stadyumlarına canlı katılım konusunda takıntılı değillerdir. Gerçekten de post-taraftarlar, uydu televizyonlarının futbol yayıncılı̆̆ına geçmesinden en iyi şekilde istifade etmekte ve taraftarı oldukları takımın maçlarını izlemek amacıyla şehirlerarası seyahatin getirdiği rahatsızlıklardan kaçınmaktadırlar. Post-taraftarlar, takımlarının maçlarını izlemek için evden ayrılmak zorunda değildir, çünkü televizyon ve video, farklı kanallarda gezinmek için sonsuz firsat sağlamaktadır (Hughson at al., 2005: 101). Özellikle de günümüz taraftarlarının, dijital platformların hızlı bir şekilde yayılması ve maçlara gitmek yerine, gerçekten daha gerçek bir hâle getirilmiş olan televizyon futboluna daha fazla rağbet ettikleri göz önüne alınacak olursa yukarıda yer alan ifade daha net bir şekilde anlaşılabilir. 


\section{DEVER, Ayhan ve Sinem Toprak ATEŞOĞLU (2021). "McDonaldlaştırma ve Simülasyon Teorileri Bağlamında Postmodernizm ve Spor”, Mavi Atlas, 9(1): 28-41}

\section{Sonuç}

Postmodernizm her ne kadar belirsizliklerle dolu olsa da, pek çok alana etkide bulunarak, bu alanların ve bu alanlara ait eserlerin değişmesinde etkili olmuştur. Postmodernizmin etki alanlarından biri olarak spor olgusu, bu çalışmada yine postmodern teoriler olan McDonaldlaştırma ve Simülasyon teorileri kapsamında açıklanmaya çalışılmıstır. Bu iki teorinin spora uyarlanması aynı zamanda postmodernizmin spora bakışını da ortaya koymaktadır.

Ritzer tarafindan ortaya konan McDonaldlaştırma teorisi, spor dâhilinde açıklanmaya çalışılırken, teorinin dört boyutu spora uyarlanmaya çalışılmıştır. Çünkü Ritzer'in teorisinin özünü bu dört boyut oluşturmakta ve açıklamalarını bu dört unsura göre şekillendirmektedir. Diğer bir ifade ile verimlilik, hesaplanabilirlik, öngörülebilirlik ve denetim boyutları, McDonaldlaştırma teorisinin özünü oluşturmaktadır. O nedenle teorinin bu dört boyutunun, sporu ne derecede açıklayabildiği önemlidir. Verimlilik boyutu, yeni yapılan stadyumlanın tamamen maçın bütün kötü koşullarda devam etmesini sağlayacak şekilde tasarlanmış olmasi; spor salonlarında verimi arttırmaya yönelik aletlerin bulunmasi; spor kulüpleri bağlamında biletin taraftarlar tarafindan internet üzerinden satın alınması; spor kulüplerinin maç sayılarında artışa gitmeleri ve buna bağlı olarak daha fazla gelir elde etmeleri; taraftarların maç esnasında tezahüratlar yapması şeklinde sporun içerisinde kendisine kolayca yer bulabilmektedir. Hesaplanabilirlik boyutu; sporda rakamların (gollerin, sayıların) önemli olduğunu, bu rakamların doğrudan bir şekilde takım başarısını rakamlarla ölçülebilir hâle getirdiğini diğer bir ifade ile spor ürünlerinin de doğrudan bir şekilde bu hesaplanabilirlik boyutunu bünyesinde barındırmasını ifade etmektedir. Öngörülebilirlik boyutu, ilk aşamada sporda biraz sorunlu gibi dursa da (ki sporu özellikle de futbolu çekici kılan aslında öngörülemez oluşudur), özellikle modern stadyumların varlı̆̆1 ve oyunun devam etmesini sağlamaya yönelik yapısı nedeniyle (verimlilik boyutuna benzer bir şekilde) spor müsabakasının oynanacağı öngörülmektedir. Denetim boyutu ise doğrudan bir şekilde sporun içerisindeki kontrol ve denetim mekanizmalarına vurgu yapmaktadır. Diğer bir ifade ile McDonaldlaştırma teorisinin özünü oluşturan dört boyut, sporun içerisinde kendisine kolay bir şekilde yer bulabilmekte ve teori, spora başarılı bir şekilde uyarlanabilmektedir.

İkinci olarak Baudrillard tarafindan geliştirilen ve akademik alanda çok ses getiren Simülasyon teorisine ait kavramlar, spora uyarlanmıştır. Baudrillard'ın teorisinin spora uyarlanma çabasının başlangıç noktası, stadyumlarda maçların seyircisiz oynanmaya başlaması ve maç görüntülerinin hiper - gerçekliğin en önemli taşıyıcısı olan televizyonlarda gösterilmesidir. $\mathrm{Bu}$ şekilde sahalar boş kalmış ancak taraftarlar, televizyon ekranlarının karşısında neredeyse gerçekten daha gerçek bir şekilde sportif müsabakaları izlemeye başlamışlardır. Bunun yanı sıra, televizyon sporu, genel anlamda izleyicilere sayısız derecede hiper - gerçeklik sunabilmek amacıyla, spor aktivitelerinde değişim de meydana getirmiştir. Bu değişimlerin en bilineni maçların hızlandırılmasıdır. Aslında oyunun hızlandırılması, ekran karşısındaki taraftarlar için konulmuş bir gerçeklik olarak düşünülebilir. Bu durum televizyon karşısında sportif aktiviteleri izleyen kişileri, ekran karşısına daha da bağlamakta, sürekli olarak simüle edilmiş gerçekliklerin daha yoğun bir şekilde izleyicilere sunulmasına neden olmaktadır. Böylece oyunda kesintiler ve monotonluk olmamaktadır.

Postmodernizm, sporu hızlandırmanın yanı sıra taraftarlar üzerinde de bir değişim meydana getirmiştir. Postmodern dönemde post-taraftarlar ortaya çıkmışır. Bu yeni taraftar tipi, geçmiş dönemdeki futbol taraftarlarına nazaran çeşitli alanlarda daha bilgili, maçları spor sahası yerine televizyon karşısında izlemeye meyilli, deplasman maçlarına gitmeye isteksiz, farklı takımların ürünlerini satın alabilmekte yapısına sahip olma gibi birtakım özelliklere sahiptir.

Postmodernizm her ne kadar sporun ve taraftarların yapısını değiştirmiş - değiştirmeye devam ediyor olsa da içerisinde bulunduğumuz Covid - 19 salgını kapsamında maçların 


\section{DEVER, Ayhan ve Sinem Toprak ATEŞOĞLU (2021). "McDonaldlaştırma ve Simülasyon Teorileri Bağlamında Postmodernizm ve Spor”, Mavi Atlas, 9(1): 28-41}

stadyumlarda seyircisiz yapıllyor olması Baudrillard'ın düşüncesinin oldukça somut bir örneği olabilir. Taraftarlar, maçları (zorunlu olarak) evlerinden izlemekte ve simüle edilmiş bir hiper gerçeklik içerisinde televizyonun kendilerine verdiklerini takip etmektedirler. Buna karşın izlenilen görüntü, bir spor karşılaşmasından daha fazla oranda bir gerçeklik içermekte, simüle edilmiş yapay gerçeklikler taraftarları adeta kendilerinden geçirmeye devam etmektedir.

\section{Kaynakça}

ABERCROMBIE, Nicholas; HILL, Stephen \& Bryan TURNER, (2006). The Penguin Dictionary of Sociology, USA: Penguin Books.

AHUVIA, Aaron \& Elif Izberk BILLGIN (2011). "Limits of the McDonaldization Thesis: Ebayization and Ascendant Trends in Post-Industrial Consumer Culture", Consumption Markets Culture, 14(4): 361-384.

ANDREWS, David (2000). "Posting Up: French Post-Structuralism And The Critial Analysis of Contemporary Sporting Culture", Handbook Sport Studies, ed. J. Coakley \& E. Dunning, London: Sage Publications.

ARSLAN, Hüsamettin (2000). Postmodern Sosyal Analiz, ve Postmodern Eleștiri, J. W. Murphy, İstanbul: Paradigma Yayınları.

BAUDRILLARD, Jean (1995). Kötülï̈̆̈̈n Şeffaflğ̆ Aşır Fenomenler Üz̧erine Bir Deneme, çev. Emel Abora ve Işık Ergüden, İstanbul: Ayrıntı Yayınları.

Bat1 Yayınları.

BAUDRILLARD, Jean (2011). Simülakrlar ve Simülasyon, çev. Oğuz Adanır, Ankara: DoğuPublication.

BRUCE, Steve \& Steven YEARLEY (2006). The Sage Dictionary of Sociology, London: Sage

CEVIZCI, Ahmet (1999). Paradigma Felsefe Sözlüğ̈i, Ankara: Paradigma Yayınları.

CHURCHILL, George (2005). McDonaldization of Sport, Erişim Tarihi: 25 Ekim 2020, (https://www.scribd.com/doc/5768906/McDonaldization-in-Sport).

DEVER, Ayhan (2013). "Futbol Taraftarlarının Yeni Mabedi: Disneystad'ların Doğuşu”, Yalova Üniversitesi Sosyal Bilimler Dergisi, 3(5), 93-106.

FEATHERSTONE, Mike (1996). Postmoderniæฺm ve Tüketim Kültürü, çev. Mehmet Küçük, İstanbul: Ayrıntı Yayınları.

GIULIANOTTI, Richard (1999). Football: A Sociology of the Global Game, London: Polity Press.

GIULIANOTTI, Richard (2004). "The Fate of Hyperreality: Jean Baudrillard and the Sociology of Sport", Sport and Modern Social Theorists, ed. Richard Giulianotti, ss. 225-239, New York: Palgrave Macmillan.

GIULIANOTTI, Richard (2015). Sport: A Critical Sociology, London: Polity Press.

HICKS, Stephen (2014). Explaining Postmodernizm Skepticism and Socialism from Rousseau to Foucault, China: Ockham's Razor Publishing.

HUGHSON, John; INGLIS, David \& Marcus FREE (2005). The Uses of Sport A Critical Study, London: Routledge.

KIVISTO, Peter (2011). Key Ideas in Sociology, USA: Sage Publications.

KIZILÇELIK, Sezgin (1996). Postmoderniẓm Dedikleri, İzmir: Saray Kitabevleri.

KIZILÇELIK, Sezgin (2002). Sefaletin Sosyolojisi, Ankara: Anı Yayıncılık 
DEVER, Ayhan ve Sinem Toprak ATEŞOĞLU (2021). "McDonaldlaştırma ve Simülasyon Teorileri Bağlamında Postmodernizm ve Spor”, Mavi Atlas, 9(1): 28-41 Kitabevi.

KIZILÇELIK, Sezgin ve Yaşar ERJEM (1996). Açıklamal Sosyoloji Söəlügü̆, Konya: Atilla

MADSEN, Ole Jacob (2014). Modernity, Encylopedia of Critical Psychology, ed. T. Teo, London: Springer.

MALCOLM, Dominic (2008). The Sage Dictionary of Sports Studies, London: Sage Publishing.

MCDONALDS REPORT (2020). Mcdonald's Report Fourth Quarter and Full Year 2019

Result and Quaterly Cash Dividend, Erişim Tarihi: 12 Kasım 2020, (https://news.mcdonalds.com/news-releases/news-release-details/mcdonalds-reports-fourthquarter-and-full-year-2019-results-and).

QUIE, Marissa. (2000). "Postmodernist Theories and the Question of Time", Time in Contemporary Intellectual Thought, ed. P. Baert, New York: Elsevier.

REDHEAD, Steven (1997) Post-Fandom and the Millennial Blues: The Transformation of Soccer Culture, London: Routledge.

RITZER, George (2011). Toplumun McDonaldslaştırlması, çev. Şen Süer Kaya, İstanbul: Ayrintı Yayınları.

RITZER, George (2012). Modern Sosyoloji Kuramlar, çev: Himmet Hülür, Ankara: Deki Basim Yayım.

SANDVOSS, Cornel (2003). A Game of Two Halves Football, Television and Globalisation, London: Routledge.

SARUP, Madan. (2004). Post - yapısalcıllk ve Postmoderniz̧m, çev. Abdulbaki Güçlü, Ankara: Bilim ve Sanat Yayınları.

SCAMBLER, Graham (2005). Sport and Society: History, Power and Culture, London: Open University Press.

SCOTT, John (2006). Sociology -The Key Concepts-, London: Routledge.

TAYLOR, Bryan (2005). "Postmodern Theory", Engaging Organizational Communication Theory and Research, ed. Steve May \& Denis Mumby, ss.113-140, London: Sage Publishing.

TURNER, Bryan (2006). The Cambridge Dictionary of Sociology, New York: Cambridge University Press.

WARING, Justin and Simon BISHOP (2015). "George Ritzer: Rationalisation, Consumerism and the McDonaldisation of Surgery", The Palgrave Handbook of Social Theory in Health, Illness and Medicine, ed. Fran Collyer, ss.488-503, London: Palgrave McMillan. 